\title{
We Decided we Would Commit Suicide but we Couldn't: The Most Unique and Functional Decision of the Young Generation during the Pandemic Situation of Covid-19
}

\author{
Farhana Yasmin * \\ Md. Alamgir Hossain ${ }^{* *}$
}

\begin{abstract}
A thematic analysis of the extreme level of depression circulating on the lockdown society during the Covid-19 situation reveals problems and challenges that the young generation faced. They expressed the hardships of surviving lockdown while ruining the fresh dreams of their fresh minds. Their ruining dreams presented as helpless, depressed, and even suicidal when they discover that none of their coping mechanism helps them. Some people decided to commit suicide but return to normal life by giving up their decision after much thought. The qualitative research design is the most appropriate design for this study considering the short period and lack of available respondents because they do not want to share these sensitive issues. In this research, through the case study, is being tried to find out the real causes of the suicidal ideation of the respondents and the KII (Key Informant Interview) method has been taken to know the parental feelings on the suicidal ideation using the snowball procedure of non-probability sampling. This article analyses the primary reason for this unique and functional decision of the young generation that "We Decided We Would Commit Suicide. But We Couldn't." In addition, highlights the emergency responses for violating their suicidal decision during the corona period.
\end{abstract}

Keywords: Covid-19, Functional Decision, Suicidal Ideation, Violating Suicidal Decision etc.

\footnotetext{
* Researcher, Social Worker, Writer, Department of Sociology, Barishal University - Bangladesh. email: farhana.soc.bu@gmail.com

*** Senior Lecturer, Computer Science and Engineering Department, Prime University, Dhaka - Bangladesh. email: alamgir.cse14.just@gmail.com
} 


\section{INTRODUCTION}

Suicide is the trigger surge and the leading cause of death. Suicide is the action of murdering oneself and suicidal behaviour refers to the plan of committing suicide. Not only physical illness but also economic, social, and mental crises are the adverse effects of Covid-19 pandemic in a very short period ${ }^{1}$. It has spread all around the globe and can affect anybody young or old, abled or disabled ${ }^{2}$. Affecting its adverse effects young generation is forced to commit suicide and are destroyed their lives and their family.

While most adults in the United States are expose to Covid-19, the disease is detected in more than 2 million children and adolescents. Severe illness is rare in adolescents, but the effects of coronavirus on adolescent well-being should not be ignored. It has wreaked havoc on their lives. Pre-pandemic, adolescents' mental health issues were already a concern. A 2019 survey of high school students reported more than 1 in 3 reported stable grief or depression, and 1 in 5 considered suicide. Data from 2001 to 2004 indicate that approximately one in three adolescents between the ages of 13 and 18 had an anxiety disorder. Studies suggest that the psychological consequences of the pandemic have worsened ${ }^{3}$.

A new study in 2021 found that more people in Bangladesh committed suicide last year than, those, died because of coronavirus. Between March last year and February 2021, there were 14,436 suicides, with 8,462 COVID-19-related deaths. Among them suicidal attitudes were more of the students. That has happened for the economic and social repercussions of the pandemic ${ }^{4}$. However, the purpose of this study to find affecting factors to the suicidal attitudes among young generation usually known as youth whose age limitation between 12 to 25 years and to analyse why they come back from their decision to commit suicide during covid-19 pandemic situation.

\section{Background of the Study}

Suicide is a worldwide public health compulsion, with many more attempts including about 800,000 deaths a year ${ }^{5}$. From Emile Durkheim's classic study Le Suicide ${ }^{6}$, it has been continually assured that suicide rates increased during and after the crisis ${ }^{7}$. Social, psychological and healthrelated effects of the Covid-19 pandemic may increase the risk of suicidal behaviour ${ }^{8}$. Moreover,

${ }^{1}$ Norina Usman, Mohammed A Mamun, Irfan Ullah, COVID-19 infection risk in pakistani health-care workers: The cost-effective safety measures for developing countries (Social Health Behavior, 2020), 76.

${ }^{2}$ Mohammed A. Griffiths, Mamun and Mark D, First COVID-19 suicide case in Bangladesh due to fear of COVID19 and xenophobia: Possible suicide prevention strategies (Asian J Psychiatr, 2020), 1.

3 Rebekah Fenton,. Covid-19 has wreaked havoc on young people's lives. We owe it to them to see this through. https://www.washingtonpost.com/opinions/covid-mental-health-teenagers/2021/01/27/99602ce2-60b3-11eb-906107abcc1f9229_story.html Retrived June, 2021.

4 Najmus Sakib, Bangladesh: Suicide claims more lives than coronavirus. https://www.aa.com.tr/en/asiapacific/bangladesh-suicide-claims-more-lives-than-coronavirus/2175200 Retrived April, 2021.

5 World Health Organization. Suicide. https://www.who.int/news-room/fact-sheets/detail/suicide Retrived June, 2021.

${ }^{6}$ Emile Durkheim, Suicide : a study in sociology, (New York, The Free Press, 1951).

${ }^{7}$ David Gunnell, Louis Appleby, Ella Arensman, Keith Hawton, Ann John, Nav Kapur, Murad Khan, Rory C O'Connor, Jane Pirkis, and COVID-19 Suicide Prevention Research Collaboration. Suicide risk and prevention during the COVID-19 pandemic.(The Lancet Psychiatry, 2020), 469.

${ }^{8}$ Mark A. Reger, PhD, Ian H. Stanley, MS, Thomas E. Joiner, PhD, Suicide Mortality and Coronavirus Disease 2019-A Perfect Storm? (JAMA Psychiatry, 2020), 1093. 
the fear of contracting the disease, fear of passing the disease on to others, emotional instability (frustration, anxiety and stress), isolation, difficulty as an economic consequence are the affecting factors of suicide during Covid-19 period $^{9}$.

Recent studies on COVID-19-related psychological crises have shown high levels of anxiety symptoms (6.3\% to $50.9 \%)$, depression (14.6\% to $48.3 \%)$, and post-traumatic stress disorder (7\% to $7 \%$ ) China, Denmark, Iran, Italy, Nepal, Spain, the United States and Turkey among the general population $(34.4 \%$ to $36 . \%)$ and stress $(7.1 \% \text { to } 61.9 \%)^{10}$. Data about universal changes in mental health among young people is rare is explained by a lively systemic review paper ${ }^{11}$.

This crisis leads to the high risk of suicidal attitudes among vulnerable groups like women, child, disabled and poor people ${ }^{12}$. However, suicide is the second most common cause of death in children aged 15-24 worldwide $^{13}$. The tendency to commit suicide among adult generation remains relatively static in the many countries ${ }^{14}$ but is expected to increase due to the epidemic ${ }^{15}$. Thus adult generation are being to suicidal ideation due to physical distance, school closures, and reduced access to mental health services during pandemic that disrupt daily routines and increase feelings of loneliness, depression, and anxiety ${ }^{16}$. According to UNESCO, suspension of school activities in 2020 affected more than $90 \%$ of the world's students ${ }^{17}$. The range of the adverse impact of COVID-19 on young populations worldwide seems unimaginable.

\section{Durkheim's Thinking on the Suicide}

Durkheim promote to study suicide because he wanted to show the light of the new science of sociology. In 1897, he published his most famous monograph "suicide". This monograph is one kind of indicator of decay in social solidarity ${ }^{18}$. Durkheim's study on the suicide begins with a definition of the phenomenon. According to him, suicide refers to "every case of death resulting directly or indirectly from a positive or negative death performed by the victim himself and which strives to produce this result". Durkheim portrayed two related ways of evaluating suicide rate among societies. Such as- one way is to compare different societies or other type of

9 Op.Cit., Griffiths, First COVID-19 suicide case in Bangladesh due to fear of COVID-19 and xenophobia: 1.

10 Jiaqi Xiong, Orly Lipsitz, Flora Nasri, Leanna M.W. Lui, Hartej Gill, Lee Phan, David Chen-Li, Michelle Iacobucci, Roger Ho, Amna Majeed, and Roger S. McIntyre. Impact of COVID-19 pandemic on mental health in the general population: A systematic review. (Journal of Affective Disorders, 2020), 55,57.

11 The DEPRESSD Project. Living Systematic Review of Mental Health in COVID-19. https://www.depressd.ca/covid-19-mental-health. Retrived June, 2021.

${ }^{12}$ Christine Moutier, MD, Suicide Prevention in the COVID-19 Era, Transforming Threat Into Opportunity. (Jama Psychiatry, 2021), 435.

${ }^{13}$ Dorney, K., Dodington, J.M., Rees, C.A. Preventing injuries must be a priority to prevent disease in the twentyfirst century. (Pediatr Res 87, 2020), 285.

${ }^{14}$ E M Guzmán, C B Cha, J D Ribeiro, J C Franklin. 2019. Suicide risk around the world: a meta-analysis of longitudinal studies. (Soc Psychiatry Psychiatr Epidemiol, 2019) 1460.

${ }^{15}$ Sabrina Brown Dr PH, Donna L. Schuman PhD. Suicide in the Time of COVID-19: A Perfect Storm. (The Journal of Rural Health, 2021), 212.

${ }^{16}$ Shweta Singh, Deblina Roy, Krittika Sinha, Sheeba Parveen, Ginni Sharma, Gunjan Joshi. Impact of COVID-19 and lockdown on mental health of children and adolescents: A narrative review with recommendations. (Psychiatry Res, 2020), 3.

${ }^{17}$ Lee Joyce. Mental health effects of school closures during COVID-19. (The Lancet Child \& Adolescent Health, 2020), 1.

${ }^{18}$ George Ritzer,. Sociological Theory. (New York: McGraw Hills, 2011), 92. 
collectively. Another way is to look at the changes in the suicide rate in the same collectively over time ${ }^{19}$.

Durkheim identified four type of suicide based on the two different degree - integration and regulation $^{20}$.

Table 1: Types and Degrees of Suicide

\begin{tabular}{ccc}
\hline Degree & Level & Suicide \\
\hline Integration & Low & Egoistic \\
\hline & High & Altruistic \\
\hline Regulation & Low & Anomic \\
\hline & High & Fatalistic \\
\hline
\end{tabular}

In table-1, if suicide is high, Durkheim calls that type of altruistic suicide. Low integration results in the increase of egoistic suicide. High regulation leads to fatalistic suicide and low leads to anomic suicide ${ }^{21}$.

\section{Durkheim's Suicide Theory and Covid-19 Pandemic}

During Covid-19 pandemic, mostly cases of suicide are egoistic and anomic. Actually, egoistic suicide takes place when some members of a society are detached from the mainstreaming social like caused by the lack of social bonds and integration program, then they are turn into despair. On the other hand anomic suicide rate rise when in a society there is famine, anarchy, deprivation of values and weak law and order.

Such suicides occur when the solidarity in the society decreases. Here the lack of solidarity of the individual with the society is the cause. The suicide that a person commits to get rid of loneliness, loneliness, frustration, failure, etc. is self-centred suicide. Individuals commit such suicides by being isolated from family, society, community etc. According to Durkheim, unmarried people are more likely to commit suicide than married people are. Such suicides have been a trend among the younger generation for a long time now due to the closure of educational institutions. When social control in a society weakened and a chaotic environment prevails in all cases, the suicide that takes place identified as anarchic suicide. Disgust arises among the people due to various socio-economic disasters in the society and peaceful life is disrupted. People choose the path of suicide to escape from this disgust and chaos. Durkheim called such suicides anarchic suicides $^{22}$. Such suicides are almost happening during corona period.

\footnotetext{
19 Jonathan H. Turner, Leonard Beeghley and Charles H. Powers. The Emmergence of Sociological Theory.( SAGE Publication. London: SAGE Publication, 2012), 275.

20 Whitney Pope, Durkheim's Suicide: A Classic Analyzed. (USA: University of Chicago Press, Chicago,1976), 1025.

${ }^{21}$ Rao, C. N. Shankar. Sociology. (New Delhi: Ram Nagar, New Delhi-110055, 2006), 706.

${ }^{22}$ Ibid.
} 


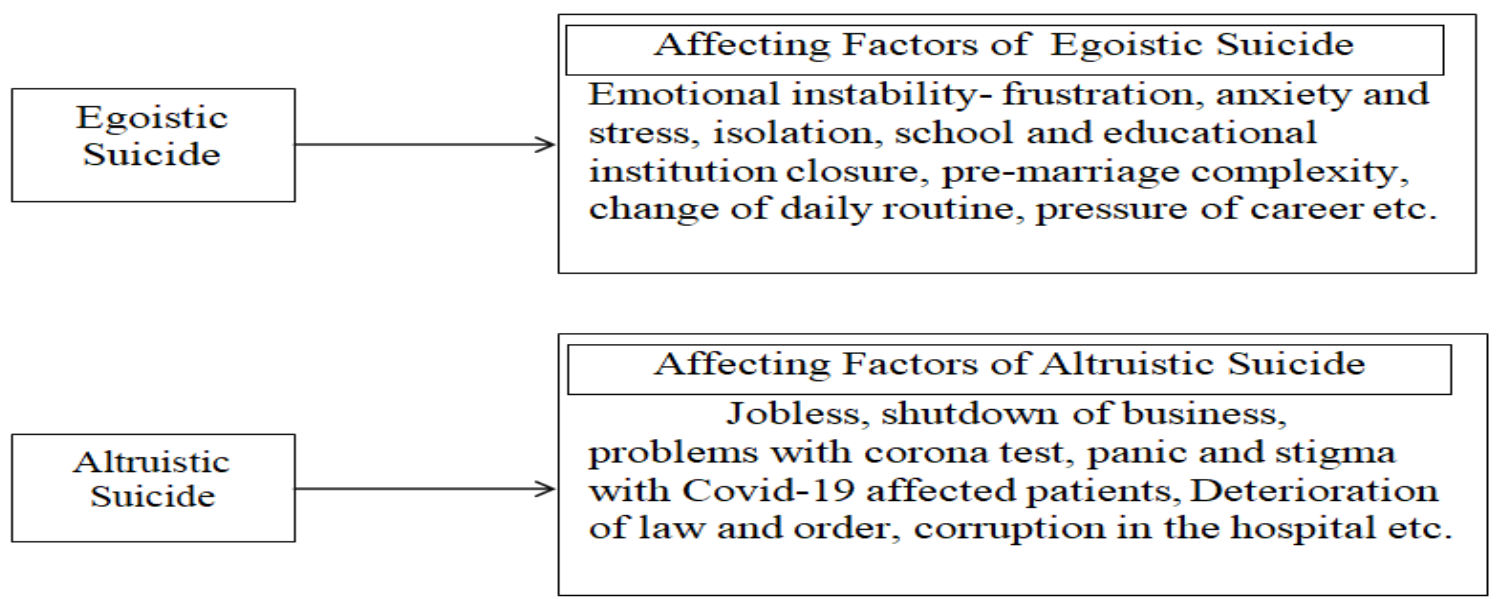

Chart 1: Affecting Factors of Egoistic \& Altruistic Suicide during Covid-19 pandemic among younger.

\section{Rationale of the Study}

Indeed, it is emergent to acknowledge the limitations of the study. Again, a small sample size means that the conclusions cannot be broadly generalize to other people and groups. However, our study design is completely appropriate for the task. The case study and KII are an analytic research method for exploring parent's suggestions in their own ways. Case studies are also useful for examining people's perspectives on sensitive issues and KII is best valid method for knowing alarming facts, comments and opinions for keeping silent not exciting mentality during critical moment. For all of these reasons, the researchers feel confident in our choice of research methods and think their research results will be valid ${ }^{23}$.

\section{Objectives of the Study}

This study is conducted to find out how the COVID-19 affected young generation and how to force suicide. In addition, the main purpose of this study is to discuss how they come back from this suicidal decision. The work also emphasizes some suggestions to cope up with any kind of crisis keeping the warm mentality.

\section{RESEARCH METHODOLOGY}

Qualitative research method is use to find answer of the research objectives. Qualitative procedure is use because the research explores the real lockdown life experiences of the young generations who came from the suicidal decision breaking this decision. For their bravery, this decision is call unique and functional decision. The study area is Jashore city under the Khulna Division of Bangladesh where found that their courage decision is most alarming issue. Due to the limited time and resources, the researcher has chosen this area randomly.

23 Michael McCauley, Sara Minsky \& Kasisomayajula Viswanath. The H1N1 pandemic: media frames, stigmatization and coping. (BMC Public Health, 2013), 9. 
Both primary and secondary data sources are used in this research to collect necessary data. Primary data are collected through case study and KII (Key Informant Interview) methods in which a checklist is used. Twenty five (20) cases and only five (5) key informant interviews have been selected using snow ball procedure of non-probability sampling. Here, young age child who's aged 12 to 25 years is required for the case study and parent and guardian of young generation who's aged 28 to 45 years are taken for the KII. The data of each respondent is attached in the appendix section at the end of the research paper. One thing is that, respondents do not want to talk about this sensitive issue. For this has been difficult to reach respondent. Moreover, thematic analysis is applied for the qualitative data analysis.

\section{DATA ANALYSIS AND INTERPRETATION}

\section{Reasons to Create Suicidal Mentality Staying Lockdown Society}

\section{Poverty and Poor Living Conditions}

With the advent of the virus, the wheel of the human economy came to a standstill. As a result, work-oriented people started losing their jobs and students also losing their tuition. The pandemic and global recession may cause over $1.4 \%$ of the world's population to fall into extreme poverty and this crisis to add as many as 150 million extreme poor by $2021^{24}$. About $13 \%$ people have been unemployed in Bangladesh due to this situation ${ }^{25}$. It says the Corona pandemic has reduced the income of one in two people worldwide. People in low-income countries in particular have suffered the most. Many have lost their jobs; their working hours are reduced $^{26}$. One of the respondents named Koushik said that, "My father is a grocer. I study at university. Dad has a lot of dreams about me but this corona is crushing that dream. I couldn't accept that my father's dream was ruined in front of my eyes so I wanted to commit suicide."

One of the respondents named Alamin argued that, "When Corona first came to Bangladesh, I was studying in the second year of Inter. In addition to my studies, I used to take care of my family by doing tuition. Because my father is a paralyzed patient and my mother has to work in someone else's house. But due to the closure of the educational institution due to Corona, my tuition also went away and my mother forbade me to go to work where she used to work. There is no solution to such a horrible situation except death, so I decided to commit suicide."

One of the respondents named Rebeka told that, "My father married me because the school was closed. The man I was married to was a businessman. He died in a road accident on his way to Dhaka on business. Then I came to my father's house and saw that I was just a burden to my parents. My father's financial situation is not good either. Seeing that my family was not doing well, I decided to commit suicide."

${ }^{24}$ World.Bank, COVID-19 to Add as Many as 150 Million Extreme Poor by 2021. (PRESS RELEASE, WASHINGTON: World Bank, 2020).

${ }^{25} \mathrm{UNB}$, Dhaka. 13pc people lost jobs due to Covid-19 pandemic: BIDS survey. (Business, Dhaka: The Daily Star, 2020).

26 Nita Bhalla, One in two people globally lost income due to the pandemic - Gallup. (News, New York: Thomson Reuters Foundation, 2021. 
One of the respondents named Zubayer said that, "Due to this corona, the father's salary was halved. Due to which there was scarcity in the family. In this way, there was always unrest in the family. Seeing all this, I decided to commit suicide."

One of the respondents named Anamika viewed that "My mother is an NGO worker because of which she had to stay outside. In this way her corona comes positive and her body condition gets much worse. At this time, she had to be admitted to the hospital and we had to spend a lot of money due to which there was a lack of family. I couldn't stand it and decided to commit suicide because I don't have a father. The cost of the family depends on"

Mental Instability

Suicide is the second leading cause of death among 15-29 year olds in the world. Every day we read the news of people committing suicide in newspapers. Most of which happen due to various reasons including failure in love, unemployment, family quarrels, failure in exams, mental problems and frustration ${ }^{27}$. Mental instability (stress, tension, anxiety, frustration) is the main leading cause of the suicide among younger during this pandemic situation.

One of the respondents named Mukit said that, "I was tired of sniffing the smell of corpses in the air. Seeing the cries of death all around, I could no longer control myself."

One of the respondents named Sathi viewed that "Loneliness seemed to swallow me up and something did not look good. So I thought I would commit suicide."

One of the respondents named Razib told that, "A depression worked all day. There was no peace in my mind. The future is dark. When I thought about all this, I would think of suicide."

One of the respondents named Sabuj said that, "Wherever I look, I see only despair, despair and despair."

\section{Disruption of Daily Routine}

Everyone has a certain routine in life and there are goals. However, because of this corona they are being shattered. As a result, the tendency of people to commit suicide is also increasing.

One of the respondents named Popi told that, "People always like to be in a certain routine. I also had a specific routine. My life routine suddenly came to a halt because of Corona which is why I am so emotionally broken and plan to commit suicide."

One of the respondents named Rishi said that, "I like volunteering a lot. Because of this corona, the parents would not let them out. As a result, I was forced to distance myself from these activities. But I couldn't accept it. So I don't think I need any more in the world."

27 Alicia Van Orman, Beth Jarosz. Suicide Replaces Homicide as Second-Leading Cause of Death Among U.S. Teenagers. (USA: PRB, 2021). 


\section{Tik-Tok Addicted-Related Stress}

At present younger people, spend their time with internet, mobile, computer and there is a tendency to make tick-tok videos of themselves. It has reached such a stage that now they are addicted to making this video. Whenever parents speak out against this behaviour, they do not accept it properly. On the contrary, they reverse creates emotional turmoil among themselves.

One of the respondents named Rasel argued that, "Since there was no work at home, I used to spend time at home making tick-tok vedio. But I became so addicted to them that when my mother snatched my device, it did not work in my head. Due to which suicide comes to mind."

One of the respondents named Daliya said that, "One afternoon we went for a walk along the river near our house and there was a boy making a tik-tok video. And my picture can be seen in that video. And when this video later went viral, I was criticized in the face of people in the neighbourhood, including my family. Seeing these, I could not control myself and decided to commit suicide."

\section{Online Gaming-Related Sufferings}

Generally, not only the younger generation but also all age's people spend a lot of their time using Facebook, Internet, and YouTube and playing various online games. However, this corona period, people are becoming more and more addicted to the internet world from house arrest. When younger are not getting support from the family for the internet expenses to play these online games then they faced mental insecurity. After that, they decide do a serious crime that is to commit suicide.

One of the respondents named Zubayer told that, "Playing online games costs internet. And I became so addicted to play PUBG games that my parents never told me to pay for the internet. That's when I made a plan to commit suicide."

Upset with the Cancelation of Exam

When the educational institutions were suddenly close due to the Corona pandemic, the ongoing examinations of many were suspended. In addition, surprisingly, the authorities have not yet been able to complete those tests. This has closed the way for students to enter their careers. This problem is causing more problems in the family. Unable to control them, the students are choosing the path of death.

One of the respondents named Razib described that, "When I had three masters exams left, the government closed the educational institution due to corona. About a year later educational authority gave the rest of the examination date. But the test was not because that date kept changing again and again. Meanwhile, after finishing my studies, l have to find a way to earn income. Unable to bear these pressures, one night I lay down and thought there was no other way but to commit suicide."

One of the respondents named Sagor said that, "Notice came for resumption of the stuck exams. I started studying and then I heard again that there will be no exams. At that time I was suffering so much that I thought to myself that I would commit suicide." 


\section{Pre-Existing Family Conflict}

There is more or less monogamy among every family member. In the same way, some of these problems are canter on the family members and even suicide. In addition, during Covid-19 pandemic period such type of suicides are usually observed.

One of the respondents named Fatema viewed that, "My husband was a drug addict and he almost tortured me. Since Corona's office was closed, he always stayed at home and treated me very badly. Then I decided to commit suicide."

One of the respondents named Mukit said that, "My parents wanted me to join the army by passing Intermediate but I wanted to be a big man by studying at university. But because of Corona, those desires came to a halt, which resulted in various kinds of unrest in the family. It was hard for me to accept them, so I decided to commit suicide the day my parents were not at home."

Pre-Marriage Relationship Complexity

Usually School, College and University students enter into relationship. Those relationships are suffering due to the long closure of the coronavirus. The parents are giving the girls in marriage because the school is close which is why boys are losing their beloved. Girls are not happy to be married based on these reason, consequently the younger generation is being force to decide commit suicide.

One of the respondents named Asif said that, "I had a relationship with a girl. Suddenly this corona's long vacation forced the girl to marry elsewhere by her parents. I couldn't accept it."

One of the respondents named Bivas argued that, "Before corona days, my girlfriend and I got married without informing concern of family. Now, during this long vacation, both of them are confined at home and no one can tell about the marriage at home. We both broke down emotionally and decided to commit suicide."

One of the respondents named Rakhi said that, "I like a boy. But my father does not want to marry me to that boy. He arranged my marriage elsewhere that is why I decided to commit suicide."

Fact of Auto Pass the Test

Educational institutions in Bangladesh are close since March last year. At this situation was out of control, the govt. did not conduct PSC, JSC, SSC and HSC examinations and announced the results based on the previous results and class performance. The results of many were not expected. As a result, many students have been committing suicide.

One of the respondents named Nisir said that, "My dream was to be a doctor. My SSC result was 4.88 and Inter result is not GPA 5 due to auto pass. I could not accept this result in any way. So I thought I'd commit suicide." 
Trouble with the Corona Test

Human knowledge about the corona virus is very limited. This lack of knowledge has caused a lot of panic among people about coronavirus. As a result, patients are being humiliated in various ways by going to the hospital for corona test. Moreover, many times patients decide to destroy themselves by not being able to tolerate such abuse. Because they have no value in life then they come to such a conclusion.

One of the respondents named Roktim viewed that, "I study at a relative's house. Suddenly my body showed signs of corona. I went to the hospital about five times to get samples for corona test and came back. Then it seems that the hospital seems to be the capital of corruption. Meanwhile, I was not getting peace until I was tested and sure. Because the people I lived in had humiliated me a lot at that time. At that time it seemed that I decided to commit suicide because of the people who were in so much trouble with me for doing this little test."

\section{Affecting Factors to Return to Normal life by Giving up the Suicidal Decision}

\section{Religious Sentiment}

Suicide is the act of ending one's own life. It is regarded as a great sin in the religious perspective and it is viewed a crime in the legal perspective. However, mostly people have viewed it as an honourable way to exist certain shameful and hopeless situation. However, most of the respondents said that their decision to commit suicide was lost to religious sentiment.

One of the respondents named Fatema viewed that, "Life means happiness and sorrow. In our scriptures, it is a form of worship to endure difficult times and to be patient. With that in mind, I dismissed the decision to commit suicide."

One of the respondents named Sathi said that, "When I decided to commit suicide I suddenly remembered a scripture saying that suicide is not the solution to any problem. So I thought that if I committed suicide, my problem would not be solved, but people would regret and criticize me."

One of the respondents named Razib told that, "In Islam, "If I commit suicide, God will never send me to paradise. I have energized my mind by thinking this religious doctrine."

One of the respondents named Zubayer viewed that, "Our religious feelings moved me when I thought of suicide because in our religion suicide is a great sin."

\section{Motivation of Relatives}

When someone says, he or she talks about suicide, or says things that sound as if the person is considering suicide, it can be very upsetting. Talking motivational and spiritual speech is the best way to control her or him. In this section, relatives play vital role.

One of the respondents named Nisir viewed that, "I wanted to become a doctor and give free treatment to poor people. But when that dream did not come true, he was struggling to survive on earth. Then one of my relatives explained to me that there are many other professions besides 
medical profession to stand by the side of poor people. That's when I realized my wrong decision."

One of the respondents named Asif said that, "When my girlfriend got married, I became emotionally depressed. Then one of my relatives told me that in addition to a lover, I have two other valuable assets in my life, they are my parents. I have to live with my head held high for them."

One of the respondents named Mukit argued that, "There was no way out except death when the family was drowning in debt. Just then a relative of mine suggested freelancing. Then I moved away from the decision to commit suicide and since then I have been earning money sitting at home in lockdown. And now I am also supporting the family."

Suggestions from Friends

When a person feels that, they have nothing to live then he/she decided to commit suicide. Suicide is the best option for them who want to end their life permanently. However, there is a great role of parents and friends for supporting of the victims. Although parents and friends are qualified, mental health provider or psychiatrist but they are the best person for the suicidal people $^{28}$.

One of the respondents named Rishi said that, "After being mentally ill for several days, I suddenly called a close friend of mine and shared all my sorrows. Since then friends have been calling me every day to keep track of me. Encourages, inspires me to move forward. Immediately after that I removed the ghost of suicide from my head."

One of the respondents named Popi viewed that, "When I felt lonely. I was overwhelmed with despair. Then a friend of mine came and stood beside me. Since then I have returned to normal life. I decided to commit suicide but that decision was changed on the advice of a friend."

One of the respondents named Sabuj told that, "The loneliness, frustration and sadness in the lockdown is making me restless. Even though I decided to commit suicide then, on the advice of my closest friend, I finally came back from the path of suicide."

Motivational Speech and Documentary Video Clips

Experts say the best way to help people prevent suicide is to put the victim in touch with those great entrepreneurs who care about the pain of a person who is thinking about suicide. The online platform is very important for him. Now, in addition to suicide, many awareness videos are on YouTube and Facebook to get yourself out of thousands of problems. It is possible to prevent suicide through this method. This is known as online resistance.

One of the respondents named Sagor argued that, "Shortly after deciding to commit suicide, a video surfaced while scrolling through Facebook. Watching the video shook my conscience and I immediately changed my decision to commit suicide."

${ }^{28}$ Udy Nydegger, Suicide Prevention: The Role of Family and Friends. (Depression \& Mood, New york: National Register of Health Service Psychologists, 2015). 
One of the respondents named Rasel viewed that, "there are many many channels on YouTube where there is a lot of awareness raising videos and I changed my decision after watching those videos."

One of the respondents named Daliya said that, "Suddenly one day I was so inspired to watch a video of a female psychologist that the word suicide in my head was completely deleted."

\section{Persecution of Conscience}

Conscience means a person with a healthy brain. When the conscience distorts, people choose the path of suicide instead of the illusion of their own life.

One of the respondents named Anamika said that, "Whenever I stood in front of the mirror, my conscience would tell me that it was not right for me to make the decision to commit suicide."

One of the respondents named Rakhi told that, "My conscience shook my whole body after I decided to commit suicide. Then it seemed that I was an educated girl. So what am I going to do as an educated girl!"

One of the respondents named Roktim viewed that, "We all accountable to society. At the end of the day we should do something for the country. Thinking about these things, I left the decision of suicide from my head."

Love for Family Members

We can't live alone in society. Mother, father, brother and sisters live together. This is family, society. The contribution of these elements in our lives is immense. And that's why we are in danger, when we are in trouble, the family comes to mind first. So it is said that, family plays a vital role controlling suicidal attitudes.

One of the respondents named Koushik told that, "An important part of life is empathy for the family. I could not commit suicide because of this sympathy."

One of the respondents named Alamin said that, "The face of the sick father was floating in front of my eyes again and again which caused me to come back from committing suicide.

One of the respondents named Rebeka viewed that, "Suddenly I wondered how my parents would survive without me. And with the help of this thought, l got rid of the heinous crime like suicide."

One of the respondents named Bivas argued that, "I love my family very much. That's why I have destroyed the decision to commit suicide by overcoming hundreds of frustrations." 


\section{Parent and Guardian's View about the Dealing with Suicidal Ideation}

\section{Raising Effective Consciousness}

Suicide is the leading cause of death among school age youth. However, suicide is preventive. Youth who are contemplating suicide frequently give warning signs of their distress. Parents, teachers and friends are a key position to notice these sings and get help. Therefore, parents should be aware whenever there is any change in the children and spending time with them.

One of the key respondents named Firoz (School Teacher) said that, "Inside this lockdown I have seen a lot of change among my children. Only when we see such a change do we eat together, watch movies, and play games so that their minds are always cheerful."

One of the key respondents named Mariya (NGO Workers) told that, "The role of a mother is more of a child than that of a father so I think every mother should give more time to spend her child besides work."

\section{Growing Unity Feeling}

There is a Bengali proverb, which says, "Unity is power". The main point of this saying is that through unity we can overcome everything. In the same way, if everyone stood by a person with a human problem, he might be able to return to normal life without having to worry having to worry about any accidents or suicides.

One of the key respondents named Firoz (School Teacher) said that, "If any member of the family is in any kind of danger then even everyone should support him by his side. Then it is possible to get rid of the suicidal facts."

One of the key respondents named Fahim (Doctor) argued that, "When children have a problem, they need to be treated in a way that makes them realize that they are not alone. They have a lot of support from their parents, friends and others."

\section{Ensuring Helpful Mentality}

We know that helping is a human quality. Everyone must have this helping mentality in daily life. Normal people in their life are mentally depressed during this pandemic situation. Therefore, at this time we should all extend a helping hand to everyone.

One of the key respondents named Bikash (Police) said that, "Suicidal people need to be treated humanely. They cannot be considered unnecessary in the society."

One of the key respondents named Mariya (NGO Workers) said that, "In the midst of the lockdown, I saw a girl next to my house and it seemed that she was very mentally disturbed. Later I called her and tried to understand her mind while taking to her. Then I explained to her that death is not the solution to everything. 
Take Time to Listen Them

There is a common saying that when someone has a mental problem, we should listen to him or her patiently and it is not to listen to him or her halfway and never get up. Based on this doctrine we should spend time with suicidal people.

One of the key respondents named Mariya (NGO Workers) said that, "The parent-child relationship should be like a friend. And they should chat with their child freely."

She also said that, "After completing all the work, I talk to my children every day according to the rule sand try to understand their attitude."

Focus on the Research

Creating new knowledge is the main objective of the research. Similarly, if there is a problem, the task of research is to find a solution by studying that problem. So we need to more research on suicide, then the root cause of the problem will be invisible.

One of the key respondents named Roshid (University Teacher) argued that, "With more emphasis on research, we can easily understand what situations people fall into and after that do not wait one minute to destroy their precious lives."

\section{RESULT AND DISCUSSION}

Suicide is one of the alarming causes of death among young generation and risk of suicidal behaviour among them is high is high rather than other during Covid-19 pandemic period in the world $^{29}$. Indeed, the economy related problem to the Covid-19 pandemic on mental health might be severe. Economic uncertainty leads to an immediate impact on suicide that is why it is regarded as the risk factor to committing suicide ${ }^{30}$. However, the study found that, fourth-fifth respondent of case study decided to commit suicide due to the lack of economic needs. Thousands of problems originate from economic problems. Based on those problems, they decided to commit suicide.

Table 2: Finding - 1 Immediate causes of the suicidal attitudes based on the economic crisis

\begin{tabular}{lll}
\hline - Extreme level Poverty & $\bullet$ Mental isolation. \\
- Being deprived of medical opportunities. & $\bullet$ Unemployment \\
- Family unrest & $\bullet$ Feeling financial insecurity etc. \\
\hline to buy internet package & & \\
\hline
\end{tabular}

${ }^{29}$ Cicek Hocaoglu, The Impact of COVID-19 Pandemic on Suicidal Behavior. In Anxiety, Uncertainty, and Resilience During the Pandemic Period - Anthropological and Psychological Perspectives. (IntechOpen, Turkey, 2021), 25.

${ }^{30}$ Leo Sher, James J. Peters. The impact of covid-19 pandemic on suicide rates. (International Journal of Medicine, 2020), 703. 
During this time of global pandemic, people are associated with suicide for social isolation and mental instability. This study showed that, due to the mental problem and instability most of the respondents of case study decided to commit suicide. There are many major problems and affecting factors towards suicidal feelings under this mental instability.

Table 3: Finding - 2 Psychological suffering related problems

\begin{tabular}{ll}
\hline$\bullet$ Anger & $\bullet$ Stress \\
$\bullet$ Fear & $\bullet$ Depression \\
$\bullet$ Tension & $\bullet$ Trauma \\
$\bullet$ Anxiety & $\bullet$ Loneliness etc. \\
\hline Tension & \\
\hline
\end{tabular}

By the way, no one had any idea about the coronavirus before. It is a completely new infections disease. That is why everyone is a little more nervous about it. Especially, during this pandemic, the younger generation is becoming more desperate and is entering the world of heinous crime like suicide. For this, suicide rate is high among them than other age group during this critical period of the country ${ }^{31}$. Moreover, there are some possible factors are responsible for the deterioration of their mental health and so they decided to commit suicide. These responsible factors are;

Table 4: Finding-3: Immediate causes of the suicidal attitudes based on the mental instability.

$\begin{array}{ll}\text { - School closure } & \text { - Online class related complexity } \\ \text { - Step by step announcement of opening of } & \text { - Pre-marital and marital related problems } \\ \text { educational institutions is not being } & \text { - More social media use } \\ \text { implemented. } & \text { - Addiction to online games } \\ \text { - Excessive regulation (Social distancing and } & \text { - On-going text cancellation } \\ \text { use of face mask) } & \text { - The pressure of career formation etc. }\end{array}$

However, the younger generation is emotionally broken because of the above reasons. As a result, they have lost control of themselves and are committing heinous sins, such as suicide.

Now, let us discuss about the most unique and functional decision of young generation that "We Decided We Would Commit Suicide. But We Couldn't." in fact, all the respondents of case study had decided to commit suicide in the midst of this on-going corona pandemic, but for various reasons, they have reversed their decision to return to normal life. For this, their decision not to commit suicide is a unique and functional decision.

\footnotetext{
${ }^{31}$ Md. Dilshad Manzar, Abdulrhman Albougami, Norina Usman and Mohammed A. Mamun. COVID-19 Suicide among Adolescents and Youths during the Lockdown: An Exploratory Study based on Media Reports. (Journal reference: Journal of Child and Adolescent Psychiatric Nursing, 2021), 3,4;
} 


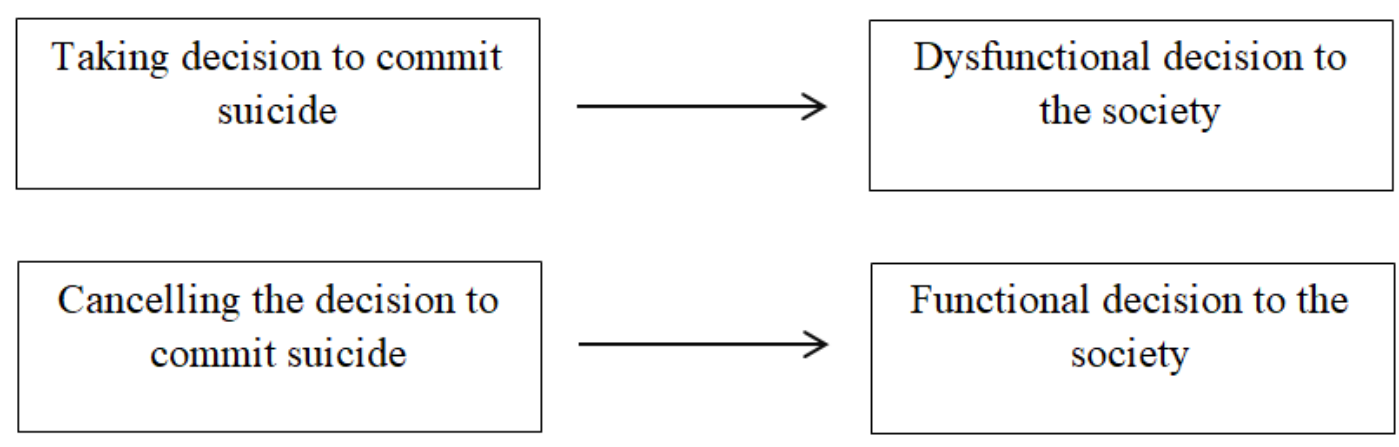

Chart 2: Functional \& Dysfunctional Decision to the Society.

For example, 4 cases out of 20 cases cancelled their decision to commit suicide for religious sentiment, 3 cases out of 20 cases cancelled listening to the motivation of relatives, then 3 cases out of 20 cases excluded their decision following to the suggestion of the friends and 4 cases out of 20 cases felt the wet love of their family and suspended their decision to commit suicide. Lastly, 3 cases out of 20 cases are forced to come out of suicide out of conscience.

Findings from the current study highlight that, everyone in society has a value in life and every human being in the society is valuable for the society. Therefore, we should not create chaos, dysfunction in the society by committing suicide except natural death. It destroys the harmony of our society. That is why postponing the decision of the respondents to commit suicide is call a functional decision of the society. Last, people concentred on suicidal ideation when they are facing problems and sufferings. It is a symptom of an underlying problem. We can ignore this problem maintaining some treatments and suggestions with the suicidal persons ${ }^{32}$.

In this study, all of the key respondents think that everyone's life is very important in building a healthy society. For this, they should stay away from the terrible chapter called suicide. They also think that if there is a physical and character change in the children and family members, they need to spend more time with them, listen to their minds, and extend a helping hand to get them out of their problems. In addition, one parent said that, more research is to be conduct on all these critical issue. From above discussion, it is clear that, after deciding to commit suicide, to come out of that decision is to win one kind of war. This is why decision of not commit suicide is functional and effective decision for the society.

\section{CONCLUSION}

To our Knowledge, the risk of suicidal behaviour of younger is high than the others ${ }^{33}$.With onset of the pandemic, the mental health of them affected by the psychological sufferings ${ }^{34}$. Covid-19 has affected family relationships, economic structure of the family. Based on these issues younger are mentally disturbed and are prone to suicide. They are becoming addicted to social

\footnotetext{
${ }^{32}$ Brazier, Yvette. What are suicidal thoughts?. (NewsLetter, Brighton: MedicalNewsToday, 2020).

${ }^{33}$ Yip PS, Cheung YT, Chau PH, Law YW. The impact of epidemic outbreak: the case of severe acute respiratory syndrome (SARS) and suicide among older adults in Hong Kong. (Crisis, 2010), 87.

34 Huang Y, Zhao N. Generalized anxiety disorder, depressive symptoms and sleep quality during COVID-19 outbreak in China: a web-based crosssectional survey. (Psychiatry Research, 2020), 2, 5.
} 
media, including mobile gaming and stress due to the excessive rules and regulation during lockdown period. Then at one point, they are stepping on the path of suicide. It is worth mentioning that, changing the suicidal behaviour is functional for society. Moreover, because of this change, the balance of society remains the balance of society. For this perspective the younger is opposing opinion about their suicidal ideation is appropriate that is "We Decided We Would Commit Suicide. But We Couldn't." and everyone should salute those who make such decisions and those who have returned to the mainstream of society. In fine, everybody should to ensure timely and adequate support for the suicidal person and should to provide proper treatment and suggestions identifying of those risk group of suicidal person. 


\section{REFERENCES}

Bank, World. 2020. COVID-19 to Add as Many as 150 Million Extreme Poor by 2021. PRESS RELEASE, WASHINGTON: World Bank.

Bhalla, Nita. 2021. One in two people globally lost income due to the pandemic - Gallup. News, New York: Thomson Reuters Foundation.

Brazier, Yvette. 2020. What are suicidal thoughts? NewsLetter, Brighton: MedicalNewsToday.

Brown, Sabrina DrPH, Donna L. Schuman PhD. 2021. "Suicide in the Time of COVID-19: A Perfect Storm." The Journal of Rural Health 211-214.

Disorders, Journal of Affective. 2020. "Impact of COVID-19 pandemic on mental health in the general population: A systematic review." 55-64.

Dorney, K., Dodington, J.M., Rees, C.A. 2020. "Preventing injuries must be a priority to prevent disease in the twenty-first century." Pediatr Res 87 282-292.

Durkheim, Emile. 1951. Suicide : a study in sociology. New York: Glencoe, Illinois : Free Press.

Fenton, Rebekah. 2021. Covid-19 has wreaked havoc on young people's lives. We owe it to them to see this through. 28 January. Accessed 05 15, 2021.

Griffiths, Mohammed A. Mamun and Mark D. 2020. "First COVID-19 suicide case in Bangladesh due to fear of COVID-19 and xenophobia: Possible suicide prevention strategies." Asian J Psychiatr 1-2.

Gunnell, David, Louis Appleby, Ella Arensman, Keith Hawton, Ann John, Nav Kapur, Murad Khan, Rory C O'Connor, Jane Pirkis, and COVID-19 Suicide Prevention Research Collaboration. 2020. "Suicide risk and prevention during the COVID-19 pandemic." The Lancet Psychiatry 468-471.

Guzmán, E. M, C B Cha, J D Ribeiro, J C Franklin. 2019. "Suicide risk around the world: a meta-analysis of longitudinal studies." Soc Psychiatry Psychiatr Epidemiol 1459-1470.

Hocaoglu, Cicek. 2021. "The Impact of COVID-19 Pandemic on Suicidal Behavior." In Anxiety, Uncertainty, and Resilience During the Pandemic Period - Anthropological and Psychological Perspectives, by Prof. Fabio Gabrielli and Dr. Floriana Irtelli, 1-17. Turkey: IntechOpen.

Lee, Joyce. 2020. "Mental health effects of school closures during COVID-19." The Lancet Child \& Adolescent Health 1.

Manzar, Dilshad, Abdulrhman Albougami, Norina Usman and Mohammed A. Mamun. 2020. "COVID-19 Suicide among Adolescents and Youths during the Lockdown: An Exploratory Study based on Media Reports." Journal reference: Journal of Child and Adolescent Psychiatric Nursing 2021, 12313 1-8. 
McCauley ,Michael, Sara Minsky \& Kasisomayajula Viswanath. 2013. "The H1N1 pandemic: media frames, stigmatization and coping." BMC Public Health 1-16.

Moutier, Christine, MD. 2021. "Suicide Prevention in the COVID-19 Era, Transforming Threat Into Opportunity." Jama Psychiatry 433-438.

Nydegger, udy. 2015. Suicide Prevention: The Role of Family and Friends. Depression \& Mood, New york: National Register of Health Service Psychologists.

Organization, World Health. 2019. Suicide. 2 September. Accessed 05 20, 2021. https://www.who.int/news-room/fact-sheets/detail/suicide.

Pope, Whitney. 1976. Durkheim's Suicide: A Classic Analyzed. Chicago, USA: University of Chicago Press.

Project, The DEPRESSD. 2021. Living Systematic Review of Mental Health in COVID-19. 12 June. Accessed June 25, 2021. https://www.depressd.ca/covid-19-mental-health.

Rao, C. N. Shankar. 2006. Sociology. New Delhi: Ram Nagar, New Delhi-110055.

Reger, Mark A., PhD, Ian H. Stanley, MS, Thomas E. Joiner, PhD. 2020. "Suicide Mortality and Coronavirus Disease 2019—A Perfect Storm?" JAMA Psychiatry 1093-1094.

Ritzer, George. 2011. Sociological Theory. New York: McGraw Hills.

Sakib, Najmus. 2021. Bangladesh: Suicide claims more lives than coronavirus. 14 March. Accessed April 20, 2021. https://www.aa.com.tr/en/asia-pacific/bangladesh-suicideclaims-more-lives-than-coronavirus/2175200.

Sher, Leo James J. Peters. 2020. "The impact of covid-19 pandemic on suicide rates." International Journal of Medicine 702-712.

Singh, Shweta ,Deblina Roy, Krittika Sinha, Sheeba Parveen, Ginni Sharma, Gunjan Joshi. 2020. "Impact of COVID-19 and lockdown on mental health of children and adolescents: A narrative review with recommendations." Psychiatry Res 1-10.

Turner, Jonathan H. Leonard Beeghley and Charles H. Powers. 2012. The Emmergence of Sociological Theory.” SAGE Publication. London: SAGE Publication.

UNB, Dhaka. 2020. 13pc people lost jobs due to Covid-19 pandemic: BIDS survey. Business, Dhaka: The Daily Star.

Usman,Norina ,Mohammed A Mamun, Irfan Ullah. 2020. "COVID-19 infection risk in pakistani health-care workers: The cost-effective safety measures for developing countries." Social Health Behavior 75-77.

VanOrman, Alicia, Beth Jarosz. 2021. Suicide Replaces Homicide as Second-Leading Cause of Death Among U.S. Teenagers. USA: PRB. 
Y, Huang, Zhao N. 2020. "Generalized anxiety disorder, depressive symptoms and sleep quality during COVID-19 outbreak in China: a web-based crosssectional survey." Psychiatry Research 1-21.

Yip PS, Cheung YT, Chau PH, Law YW. 2010. "The impact of epidemic outbreak: the case of severe acute respiratory syndrome (SARS) and suicide among older adults in Hong Kong." Crisis 86-92. 